\title{
Effect of Concept Attainment Models and Self-Directed Learning (SDL) on Mathematics Learning Outcomes
}

\author{
Moch. Sukardjo \\ Dr., Jakarta State University, Indonesia, msoekardjo@unj.ac.id
}

\section{Mohamad Salam}

Dr., Department of Mathematics Education, Halu Oleo University, Kendari, Indonesia, mohamad.salam@uho.ac.id

This study examined the effect of the concept attainment learning model and selfdirected learning (SDL) on mathematics learning outcomes. This research is a quasi-experiment conducted in SMA Negeri 6 Kendari, Indonesia, grade 10 th. The sample in this study was grade 10th (3rd) as the experimental class and grade 10th (5rd) as the control class. In the experimental class, the learning model of the Attainment Concept was given and the control class was given a direct learning model. The dependent variable is the learning outcomes of mathematics, while the learning model and Self-Directed Learning (SDL) are independent variables. The study design uses $2 \times 2$ by levels. The findings of the research results are: (1) the mathematics learning outcomes taught with the Concept Attainment learning model are higher than the direct learning model, (2) there is an influence of the interaction between the learning model and SDL on mathematics learning outcomes, and (3) mathematics learning outcomes on students who are high SDL and taught with the Concept Attainment learning model are higher than the direct learning model, and students who have low SDL are taught with the Concept Attainment learning model that is lower than the direct learning model.

Keywords: concept attainment model, direct learning, self-direct learning, learning outcomes, mathematics learning

\section{INTRODUCTION}

Learning mathematics is a relatively permanent process of change in one's behavior and the change is the result of acquiring knowledge or skills related to communication, quantity, space, and structure (Seel, 2012; Adeniji et. al., 2018; Tabach \& Nachlieli, 2016). The results of learning mathematics are called mathematics learning outcomes. Mathematical learning outcomes are the ability or mastery of students' mathematical material which includes aspects of knowledge, attitudes, and mathematical skills in the 
form of facts, rules, formulas and procedures as a result of the learning process that is measured by tests and then accumulated in the form of numbers or symbols (Gatti et. al., 2019; Baroody \& Dowker, 2013).

Problems that occur in the present school are learning outcomes or student learning achievement towards low mathematics subjects. Low learning outcomes are caused by various factors including learning models, learning approaches, students 'initial abilities, student intelligence, ability to understand mathematical language, and students' attitudes towards mathematics. (Salam et. al, 2019; Moyer-Packenham \& Westenskow, 2013; Zhang et. al, 2018; Huang et. al, 2017; Capar \& Tarim, 2015; Maonde et. al, 2015). Facts from the low learning outcomes of mathematics were also found in SMA Negeri 6 Kendari, which is indicated by the inability of students to answer the questions given by the teacher and consequently student learning outcomes are low. The average student learning outcomes of SMA Negeri 6 Kendari in grade 10 for the last three years from 2016 to 2018 was 64.98; 63.01; and 61.22. This shows that student mathematics learning outcomes have not yet reached the minimum completeness criteria (MCC) of 75.0 set by the school. In 2016, the percentage of students under MCC was $72.08 \%$; in 2017, the percentage of students under MCC was $80.12 \%$ and in 2018 the percentage of students who scored below MCC was $87.36 \%$. (Source: Vice-principal of SMA Negeri 6 curriculum in Kendari). These results indicate that the average value of mathematics learning outcomes over the past three years tends to decrease and values below MCC tend to increase.

Various studies have been conducted to improve mathematics learning outcomes, namely: Various studies have been conducted to improve mathematics learning outcomes, namely: Salam et. al (2019), conducting research in grade 11 of SMA Negeri 6 Kendari, the results obtained that mathematics learning outcomes can be improved through integrative learning models; learning models and spatial intelligence have an interaction effect on mathematical results. Maonde et. al (2016) researched Kendari City High School, mathematics learning achievement can be improved by cooperative learning models; Learning and motivation models have an interaction effect on mathematics learning achievement. The results of Suarsana's study (2019) at SMA Negeri 4 Singaraja, mathematics learning outcomes can be improved by online posing problems. Abed et. al (2019), mathematics learning outcomes can be improved through a jigsaw strategy. This gives meaning to mathematics learning outcomes that can be improved by learning models, strategies or learning methods. Research result Mulbar et. al (2017), Rahman \& Ahmar (2017), Rahman et. al (2016), Wang et. al (2015), Leon et. al (2015), Park et. al (2016) explained that mathematics learning outcomes are influenced by learning styles, learning motivation, anxiety, and intelligence. This shows that mathematics learning outcomes are influenced by internal and external factors. Internal factors are factors that originate in students, including learning styles, learning motivation, anxiety, and intelligence. While external factors are factors originating from outside students, including models, approaches, strategies, or learning methods applied by teachers in class. 
One of the causes of the low learning outcomes of students of SMA Negeri 6 Kendari is the lack of understanding of mathematical concepts characterized by the inability of students to understand correct ideas and express knowledge acquired during learning both verbally and in writing (source: one of the mathematics teachers in high school Negeri 6 Kendari). While understanding mathematical concepts is one of the main goals of mathematics subjects. The purpose of learning mathematics in schools is that students can understand mathematical concepts, explain inter-conceptual relationships and apply concepts or algorithms, flexibly, accurately, efficiently, and precisely, in problemsolving (BSNP, 2006). This objective is relevant to the School Mathematical Standards Principles described in NTCM (2000), that students learn mathematics to develop and deepen understanding of mathematical concepts and relationships by making, comparing, and using various representations (Minarni et. al., 2016; Agrawal \& Morin, 2016; Richland et. al. 2017). Sumarni et. al. (2018), understand the concept that allows us to understand something, transform it into information that is discussed by students in performing procedures (algorithms) that are flexible, correct, efficient and precise. This shows a mathematical concept that supports the development of mathematical concepts based on generalizations from the comparison of students to the subject matter discussed.

Understanding mathematical concepts are very important because it can facilitate students in learning mathematics which is the basis and important stages in a series of learning mathematics (Weintrop et. al., 2016; Mullis \& Martin, 2017; Kholodnaya, 2016). However, in reality, understanding of the mathematical concepts held by students is still low (Rensaa, 2014; Ningsih \& Paradesa, 2018; Sumarni et. Al., 2018). This is because students tend to memorize a concept learned without understanding the concept. One of the factors that cause a low understanding of mathematics concepts which results in low mathematics learning outcomes is the learning model applied by the teacher (Rahman et al, 2016; Razak, 2016; Nasution \& Surya, 2017). The learning model used by the SMA Negeri 6 Kendari teacher in grade 10 in mathematics learning is direct (source: mathematics teacher SMA Negeri 6 Kendari). The direct learning model is a teacher-centered learning model that teaches targeted knowledge or skills or both sequentially with systematic steps (Estes \& Mintz, 2016; Burden \& Byrd, 2016). The direct learning model is used to transfer knowledge to students directly (Chase \& Klahr, 2017). However, the direct learning model is a learning model that is planned, organized, controlled and focused on achieving learning objectives (Borich, 2017). This shows that the direct learning model is centered on the teacher without regard to the independence and activeness of students. As result students in passive learning only receive knowledge from the teacher alone, students have a high dependence on others to learn, and the teacher does not practice the independence of student learning. The teacher must pay attention to the activeness of students in learning by applying learning models that are appropriate to the character of students and the learning material being taught.

Self directed learning (SDL) is an increase in knowledge, skills or performance pursued by each individual for himself by using anything, anytime, anywhere, and taking initiative without the help of others in meeting his learning needs (Herlo, 2017; Din et. 
al., 2016). This shows that learning independence is an important skill that a person has to adapt to new situations and environments to get resources and learn quickly in overcoming problems, work or new situations they face (Tan et. al., 2011). SDL is a habit possessed by someone to try to solve the problems they face to improve better performance (Brockett \& Hiemstra, 2018). SDL can be considered as a process and purpose (Nasri \& Mansor, 2016). SDL is seen as a process in which students are responsible for controlling their learning, SDL is seen as a goal that focuses on the desires and tendencies of students for self-direction. SDL has indicators, namely: a) Ownership of learning is its responsibility in identifying learning gaps and setting learning goals, b) Self-management and self- supervision is the ongoing process of managing tasks, time and resources to make improvements in taking action to meet learning objectives, c) Extension of learning is making connections between scientific disciplines, relationships between formal and informal learning and interests in and out of school (Khiat, 2017; Tan \& Koh, 2014; Bagheri et. al., 2013).

Based on the opinions above, SDL is a habit that is owned by someone in increasing knowledge, skills and performance in various ways through mastering learning material with their own efforts to achieve goals, which can be measured through the ownership of learning, self-management, and self-monitoring, and Extension of learning. To improve the understanding of mathematical concepts, an appropriate learning model is needed. One of the learning models that can be used to improve the understanding of students' mathematical concepts is the learning model of concept attainment. Concept attainment learning models are designed to help students deepen and enrich their understanding of the concepts they already have and deepen concepts related to the concepts they have (Eggen \& Kauchak, 2012; Estes \& Mintz, 2016). This definition illustrates that concept attainment models are designed to help students achieve two types of learning goals, namely: (1) developing their understanding of concepts, and (2) developing students' critical thinking skills. Meanwhile, Moore (2015), the concept attainment model is a learning strategy that uses a structured inquiry process. Another definition related to the concept attainment model as explained by Bruner et. al., (1967) in Joyce et. al., (2015) that the model of learning the achievement of concepts is a process of finding and listing the characteristics that can be used to distinguish appropriate examples from inappropriate examples from various categories. This process ensures that students will learn the traits or traits that define a particular concept or traits that have been determined and can distinguish these traits from those with other traits that are not by the definition. Kilbane \& Milman (2014) explain that the concept attainment model is a dynamic, interactive teaching model, which supports students' in-depth understanding of the concept and development of conceptual knowledge. The conceptual knowledge in question includes knowledge of the relationship between ideas such as classifications and categories. The development of conceptual knowledge depends on understanding specific concepts that together form larger ideas.

Eggen \& Kauchak (2012), describes the phases of concept attainment models in the following table 1 . 
Table 1

Phases in Implementing Lessons using the Concept Attainment Model

\begin{tabular}{ll}
\hline Phase & Description \\
\hline $\begin{array}{l}\text { Phase 1: } \\
\text { Introduction }\end{array}$ & $\begin{array}{l}\text { The teacher introduces the lesson and explains how the activity will } \\
\text { be conducted. }\end{array}$ \\
$\begin{array}{l}\text { Phase 2: Examples } \\
\text { and hypothesizing }\end{array}$ & $\begin{array}{l}\text { Students are presented with an example (or possibly two examples) } \\
\text { and a nonexample, and they hypothesize possible labels for the } \\
\text { concept based on the initial example(s) and non-example }\end{array}$ \\
& $\begin{array}{l}\text { The analysis cycle. Additional examples and nonexamples are } \\
\text { presented, and students eliminate existing hypotheses and add new }\end{array}$ \\
ones based on the new examples (and non-examples) \\
$\begin{array}{l}\text { analysis cycle } \\
\text { Phase 4: Closure } \\
\text { and application }\end{array}$ & $\begin{array}{l}\text { a single hypothesis is isolated and defined, and additional examples } \\
\text { are analyzed based on the definition. }\end{array}$ \\
\hline
\end{tabular}

Concept attainment learning model is a student-centered learning model and deliberately designed to help students achieve two objectives, namely: (1) build and develop their understanding of the concept, and (2) developing abilities students' critical thinking, by the way the teacher classifies or shows the right examples and non-examples structurally from a concept that he imagines, while students make hypotheses about what the concept might be, analyze their hypotheses by looking at examples and non-examples, and finally arrive at on the concept in question.

The reason for the low learning outcomes of mathematics at SMA Negeri 6 Kendari is the low understanding of students' mathematical concepts and inaccurate learning models that do not pay attention to Self Directed Learning (SDL). Therefore it is necessary to conduct research by applying the concept achievement model, and how it relates to SDL in improving mathematics learning outcomes, with the title "Effect of Concept Attainment Models and Self-Directed Learning (SDL) on Mathematics Learning Outcomes". This study aims to determine: (1) the influence of differences in learning models on mathematics learning outcomes, (2) the effect of interactions between learning models and SDL on mathematics learning outcomes, (3) differences in mathematics learning outcomes between students taught with concept attainment models and directly on students who have high SDL, and (4) differences in mathematics learning outcomes between students who are taught with concept attainment models and directly on students who have low SDL.

\section{METHOD}

This research was conducted at SMA Negeri 6 Kendari grade10 ${ }^{\text {th }}$, to determine the effect of the learning model and SDL on mathematics learning outcomes. The variables in this study are mathematics learning outcomes as the dependent variable, while the learning model is the independent variable and SDL as the moderator variable. The research method used is quasi-experimental with a $2 \times 2$ design by the level (Maxwell et. Al., 2018). For more details, the design of this study can be seen in table 2 below. 
Table 2

Design by Level $2 \times 2$.

\begin{tabular}{lll}
\hline \multirow{2}{*}{ SDL $(\mathrm{B})$} & Learning Model $(\mathrm{A})$ & \\
\cline { 2 - 3 } & Concept Attainment $\left(\mathrm{A}_{1}\right)$ & $\operatorname{direct}\left(\mathrm{A}_{2}\right)$ \\
\hline High $\left(\mathrm{B}_{1}\right)$ & $\mathrm{A}_{1} \mathrm{~B}_{1}$ & $\mathrm{~A}_{2} \mathrm{~B}_{1}$ \\
Low $\left(\mathrm{B}_{2}\right)$ & $\mathrm{A}_{1} \mathrm{~B}_{2}$ & $\mathrm{~A}_{2} \mathrm{~B}_{2}$ \\
\hline
\end{tabular}

$\mathrm{A}_{1} \mathrm{~B}_{1}$ : groups of students taught by concept learning achievement models for students who have high SDL, $\mathrm{A}_{1} \mathrm{~B}_{2}$ : Groups of students taught by concept learning models for students who have low SDL, $\mathrm{A}_{2} \mathrm{~B}_{1}$ : Groups of students taught in the model directly to students who have high SDL, $\mathrm{A}_{2} \mathrm{~B}_{2}$ : Student groups are taught with a direct learning model for students who have low SDL.

The determination of the experimental class and control class is done by simple randomization and grade $10^{\text {th }}\left(3^{\text {rd }}\right)$ which is selected as the experimental class and grade $10^{\text {th }}\left(5^{\text {rd }}\right)$ as the control class. In the experimental class taught by concept attainment models and control classes taught with direct learning models.

Variables of mathematics learning outcomes use tests in an objective form. Before the test is used, it is first validated by two experts, namely the teacher and mathematics lecturer. Then, testing by proving to try on class 10 students of SMA Negeri 6 Kendari who are not research samples and they have studied the material being tested. Because the test used is multiple choice with a score of 0 if the answer is wrong and a score of 1 if the answer is correct or dichotomous, then the validity test uses biserial point correlation and the reliability test uses Kuder-Richardson-20 (Kaplan \& Saccuzzo, 2017). The results of the validity test of 40 items agreed to try, 35 items were declared valid with a reliability level of 0.85 . SDL variable (moderator variable) is measured using a questionnaire consisting of 40 statements, using a Likert scale modification with four scales, namely: $4=$ always, $3=$ often, $2=$ sometimes, and $1=$ never $($ Croasmun $\&$ Ostrom, 2011; La Trobe \& Acott, 2000). Before the questionnaire was used, it was validated by experts and tested in class 10 of SMA Negeri 6 Kendari. The Validity test uses product-moment correlation and reliability using Cronbach's alpha (Andrew \& Pedersen, 2018). The results of the validity test of 40 items are all valid with a reliability level of 0.78

Before being given treatment, the experimental class and the control class were given an SDL test. The SDL test results are then grouped into three categories, namely high, medium and low. Students included in the high and low categories as many as 48 people were taken as research subjects with full details in table 3 below.

Table 3

The Number of Research Subjects for Each Cell

\begin{tabular}{lll}
\hline \multirow{2}{*}{ SDL (B) } & Learning model (A) \\
\cline { 2 - 3 } & Concept attainment (A1) & Direct (A2) \\
\hline High (B1) & 12 & 12 \\
Low (B2) & 12 & 12 \\
Sum & 24 & 24 \\
\hline
\end{tabular}


Data obtained after being given treatment were analyzed using descriptive and inferential statistics. Descriptive statistics are used to explain the state of mathematics learning outcomes data in the form of averages, standard deviations, ranges, minimum values and maximum. Inferential statistics are used to test hypotheses with the two-way ANOVA technique and Dunnet t-test as a further test (Judd et. Al., 2017). Before testing the hypothesis, an analysis prerequisite test was carried out, namely the test for normality and homogeneity.

\section{FINDINGS}

The results of descriptive data analysis of mathematics learning outcomes taught by concept attainment learning models and immediately presented in table 4 below.

Table 4

Results of Descriptive Analysis

\begin{tabular}{lllllll}
\hline Variable & $\begin{array}{l}\text { Sum of } \\
\text { data }(\mathrm{n})\end{array}$ & Average & $\begin{array}{l}\text { Std. } \\
\text { Deviation }\end{array}$ & Minimum & Maximum & Range \\
\hline A1 & 24 & 77.1 & 9.0 & 57.1 & 94.3 & 37.2 \\
A2 & 24 & 73.0 & 7.8 & 57.1 & 82.9 & 25.8 \\
A1B1 & 12 & 87.9 & 5.0 & 80.0 & 94.3 & 22.9 \\
A2B1 & 12 & 74.5 & 8.0 & 60.0 & 82.9 & 22.9 \\
A1B2 & 12 & 66.4 & 4.9 & 57.1 & 71.4 & 14.3 \\
A2B2 & 12 & 71.4 & 7.6 & 57.1 & 82.9 & 25.8 \\
\hline
\end{tabular}

The results in table 4 provide mathematical learning outcomes of students taught with concept attainment learning models (A1) having an average of 77.1 and standard deviation 9.0, range 37.2, minimum values 57.1 and maximum 94.3. The mathematics learning outcomes of students taught with the direct learning model (A2) have an average of 73.0 and a standard deviation of 7.8 , a range of 25.8, a minimum value of 57.1 and a maximum of 82.9 .

Average mathematics learning outcomes of students taught with concept attainment learning models for students who have high SDL (A1B1) is 87.9 and standard deviation 5.0, with a range 22.9, minimum value 80.0 and maximum value 94.3. Mathematics learning outcomes of students taught with a direct learning model for students who have high SDL (A2B1) have an average of 74.5 and standard deviation 8.0, with a range of 22.9, a minimum value of 60.0 and a maximum value of 82.9 .

The average score of mathematics learning outcomes of students taught with concept attainment learning models in students who have low SDL (A1B2) is 66.4 and the standard deviation is 4.9 , with a range of 14.3 , a minimum value of 57.1 and a maximum value 71.4. Mathematics learning outcomes taught by students with a direct learning model for students who have a low SDL (A2B2) have an average of 71.4 and a standard deviation of 7.6, with a range of 25.8, a minimum value of 57.1 and a maximum value of 82.9 . 
The results of the normality test data groups A1, A1, A1B1, A2B1, A1B2, and A2B2 are presented in the following table 5 .

Table 5

Data Normality Test Results

\begin{tabular}{lllllll}
\hline Statistics & A1 & A1B1 & A2 & A1B2 & A2B1 & A2B2 \\
\hline $\mathrm{N}$ & 24 & 12 & 24 & 12 & 12 & 12 \\
Kolmogorov-Smirnov Z & .902 & .609 & .728 & .620 & .872 & .510 \\
Asymp. Sig. (2-tailed) & .389 & .853 & .664 & .836 & .433 & .957 \\
\hline
\end{tabular}

a. Test distribution is Normal.

b. Calculated from data.

The results in table 5 show that the value of Asymp. Sig. (2-tailed) for all groups of data greater than $\alpha=0.05$. This means that all data groups A1, A1, A1B1, A2B1, A1B2, and A2B2 come from normally distributed populations.

The homogeneity test results from data groups A1 and A2 obtained Fcount value $=1.33$ smaller than Ftable value $=2.01$. This shows the data groups $\mathrm{A} 1$ and $\mathrm{A} 2$ are homogeneous. Testing the homogeneity of data A1B1, A2B1, A1B2, and A2B2 using the Levene test. The test results are obtained with the Sig. $=0.077$ greater than $\alpha=0.05$ (table 6). These results provide homogeneous meanings of data groups A1B1, A2B1, A1B2, and A2B2.

Table 6

The Homogeneity Test Results of Data Groups A1B1, A2B1, A1B2, and A2B2

Test of Homogeneity of Variances Learning Outcomes

\begin{tabular}{llll}
\hline Levene Statistic & df1 & df2 & Sig. \\
\hline 2.439 & 3 & 44 & .077 \\
\hline
\end{tabular}

The statistics used to answer the research question are two-way ANOVA. The two-way ANOVA results using IBM SPSS Statistics 20 are presented in the following table 7.

Table 7

Two-way ANOVA Results

Tests of Between-Subjects Effects

Dependent Variable: Learning Outcomes

\begin{tabular}{llllll}
\hline Source & $\begin{array}{l}\text { Type III Sum of } \\
\text { Squares }\end{array}$ & Df & Mean Square & F & Sig. \\
\hline Corrected Model & $3022.214^{\mathrm{a}}$ & 3 & 1007.405 & 23.437 & .000 \\
Intercept & 270435.175 & 1 & 270435.175 & 6291.515 & .000 \\
Model & 207.917 & 1 & 207.917 & 4.837 & .033 \\
SDL & 1806.880 & 1 & 1806.880 & 42.036 & .000 \\
Model * SDL & 1007.417 & 1 & 1007.417 & 23.437 & .000 \\
Error & 1891.301 & 44 & 42.984 & & \\
Total & 275348.690 & 48 & & & \\
Corrected Total & 4913.515 & 47 & & & \\
\hline
\end{tabular}

a. R Squared $=.615$ (Adjusted R Squared $=.589$ ) 
Research Questions 1: Are there differences in the influence of concept attainment learning models and direct learning models on mathematics learning outcomes?

The hypothesis tested is the mathematics learning outcomes of students who are taught with higher than concept attainment learning models than direct learning. The results variance analysis (table 7) among the model obtained a value of $F=4.837$ with the sig value 0.033 which is smaller than $\alpha=0.05$. This shows that there is the influence of concept attainment learning models and direct learning models on the learning outcomes of mathematics. The results of further tests using t Dunnet are presented in the following table 8 .

Table 8

Summary of Advanced Test Results A1 vs A2

\begin{tabular}{llll}
\hline Compared Groups & Df & $\mathrm{t}_{\text {count }}$ & $\mathrm{t}_{\text {table }(\alpha=0.05)}$ \\
\hline A1 with A2 & 44 & 2.20 & 1.68 \\
\hline
\end{tabular}

The results in table 8 obtained a value of $\mathrm{t}_{\text {count }}=2.20$ greater than the $\mathrm{t}_{\text {table }}$ value $(\alpha=$ $0.05)=1.68$ with free degrees 44 . These results mean that the mathematics learning outcomes of students taught with concept attainment learning models are higher than direct learning.

Research Questions 2: Is there an interaction effect between the learning model and SDL on mathematics learning outcomes?

The results in table 7 of the model $*$ SDL are obtained $\mathrm{F}=23.437$ with the sig value. $=$ 0.00 less than $\alpha=0.05$. These results indicate that there is a significant difference between the learning model and SDL on student mathematics learning outcomes. The effect of the interaction between the learning model and SDL on mathematics learning outcomes is $61.5 \%$ which is indicated by the value of $\mathrm{R}$ Squared $=0.615$.

\section{Research Questions 3: Is there a difference in mathematics learning outcomes between students who are taught with the concept attainment learning model and directly to students who have high SDL?}

The hypothesis to be tested in question 3 is the learning outcomes of mathematics taught by the learning model of concept attainment in students who have SDL higher than the direct learning model. The statistics used to test this hypothesis are the Dunnet t-test. The results of the Dunnet t-test are presented in the following table 9.

Table 9

Summary of Advanced Test Results

\begin{tabular}{lllll}
\hline No & Compared Groups & Df & $\mathrm{t}_{\text {count }}$ & $\mathrm{t}_{\text {table }(\alpha=0.05)}$ \\
\hline 1 & A1B1 with A2B1 & 44 & 4.98 & 1.68 \\
2 & A1B2 with A2B2 & 44 & -1.87 & 1.68 \\
\hline
\end{tabular}

The results in table 9, A1B1 with $\mathrm{A} 2 \mathrm{~B} 1$, get the value tcount $=4.98$ greater than the ttable value $=1.68$. These results mean that the mathematics learning outcomes of 
students who are taught with a learning model of concept attainment are higher than the direct learning model in students who have high SDL.

Research Questions 4: Are there differences in mathematics learning outcomes between students who are taught with the concept attainment learning model and directly on students who have low SDL?

The results in table 9, A1B2 with A2B2 obtained the value of $\mathrm{t} \_$count $=-1.87$ smaller than the value of $-\mathrm{t} \_$table $=-1.68$ in the real level $\alpha=0.05$. The results show that the mathematics learning outcomes of students taught with the concept attainment model are lower than direct learning in students who have low SDL.

\section{DISCUSSION}

This study aims to investigate the effect of concept attainment and SDL learning models on mathematics learning outcomes.

The first finding is the mathematics learning outcomes of students who are taught with a concept attainment model higher than the direct learning model. This finding is shown by the average score of mathematics learning outcomes taught by the concept attainment model (77.1) higher than the direct learning model (73.0). Also, using the Dunnet t-test, it was concluded that the average learning outcomes of the experimental class were higher than the control class, which meant the learning outcomes of students taught using the model concept attainment were better than the direct learning model significantly. This is because the model concept attainment is an inductive learning model, which is designed by the teacher to help students learn concepts and train students to practice high-level thinking skills so that their mathematics learning outcomes increase (Egen \& Kauchak, 2012). In addition, the learning model of concept attainment is very relevant to the teaching of mathematics because this model can foster understanding of concepts and principles so as to foster the power of thinking logically, critically, systematically and others (Mondal, 2013). Model concept attainment is a learning model that aims to help students understand a concept, it is more appropriate when the emphasis on learning focuses on introducing new concepts so that they can practice high-level thinking skills (Sharma \& Pachauri, 2016). The concept attainment learning model can also improve mathematical reasoning abilities (Angraini et. Al., 2018). This shows that if students are taught with a concept attainment model they will understand mathematical concepts in depth so that they can improve critical thinking skills and mathematical reasoning, which results in students' mathematics learning outcomes also increase. Unlike the direct learning model that only teaches knowledge so that when students learn more complex mathematics they will experience difficulties and consequently students' mathematics learning outcomes are low.

The second finding is that there is an interaction between the learning model and SDL on mathematics learning outcomes. This finding is visualized in the following figure 1. 


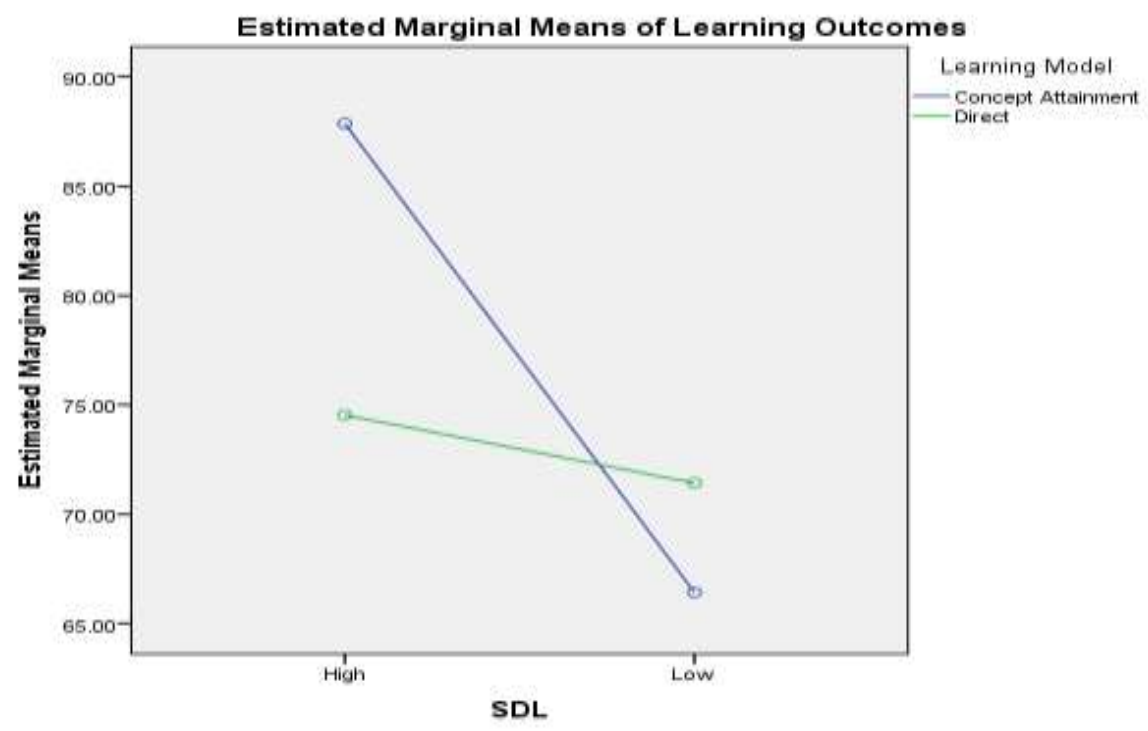

Figure 1

Interaction of Learning Models and SDL on Mathematics Learning Outcomes

Figure 1 gives the meaning that the mathematics learning outcomes taught with the learning model of concept attainment in students who have high SDL are higher than the direct learning model, whereas, for students who have low SDL, students who are taught with concept achievement learning models are lower than the learning model directly. The concept of attainment learning model is a student-centered learning model that aims at active students in learning. As a result, in the learning model concept attainment requires SDL in learning and looking for various sources that support their understanding of learning. Meanwhile, the direct learning model is a teacher-centered learning model so students in learning become passive. This means that students who have a high SDL are very suitable if taught with a concept attainment learning model, while students who have a low SDL are more apt to be taught with a direct learning model. This finding is in line with Markant et. al. (2016), Rashid \& Asghar (2016) that student-centered learning models will increase student involvement in learning which results in increased student learning outcomes. Rana, et. al. (2016) students who have SDL can organize learning so that they are able to solve learning problems. Studentcentered learning can improve SDL covering: (1) students are more active in learning mathematics; (2) students have more initiative in learning mathematics; (3) students are more independent in learning mathematics (Takaendengan \& Santosa, 2018).

The third finding is the result of learning mathematics in students who have a high SDL and are taught by a model of attainment higher concepts than the direct learning model. This finding is shown by the average score of mathematics learning outcomes of students who have a high SDL and are taught with the concept attainment model (87.9) and (74.5) taught by the direct learning model. The results of testing the hypothesis 
using the Dunnet t-test, it was concluded that significantly, mathematics learning outcomes in students who had high SDL were higher than the direct learning model. These results are in line with Alotaibi (2016) that students who have high SDL with learning models that encourage students to be actively involved in learning will improve students' academic performance, and in turn, their learning outcomes can be improved.

Students who have high SDL will develop their ability to think critically by using anything, anytime, anywhere, and take initiative without the help of others in meeting their learning needs in order to improve their learning outcomes (Herlo, 2017; Din et. al., 2016). Because SDL has emphasized the importance of process, personal, and contextual factors (Sawatsky et. al., 2017). Students who are taught with concept attainment learning models have a positive impact on independent learning attitudes and skills (Akgunduz \& Akinoglu, 2016). While the direct learning model does not encourage students to understand concepts and high-level thinking because the teacher dominates learning in the classroom so that communication between teachers and students in the class becomes small (Nystrand et. al., 2003). As a result, students who have high SDL will feel bored with receiving the learning given by the teacher, resulting in low student mathematics learning outcomes.

The fourth finding is the result of learning mathematics in students who have a low SDL and are taught with a model of achieving concepts that are lower than the direct learning model. This finding is shown by the average score of students' mathematics learning outcomes who have low SDL and are taught by the concept learning model (66.4) and (71.4) taught by the direct learning model. The results of testing the hypothesis using the Dunnet t-test, it was concluded that significantly, the mathematics learning outcomes of students who had a low SDL were lower than the direct learning model. This is because students who have low SDL are unable to solve problems independently, always depend on others, have low motivation in learning and tend to be passive in the learning process. As a result, students who have low SDL need help from teachers who are active in learning that can challenge students to truly understand learning material (Silen \& Uhlin, 2008). This shows that students who have low SDL are very suitable when taught with a teacher-centered direct learning model. While students who have low SDL feel embarrassed to explore their knowledge so that they do not participate in learning interactions (Paulhus et. al., 2002; Kim, 2002). As a result, when taught with a learning model concept attainment that requires active students in learning to be passive, so they do not understand mathematical concepts and consequently, the learning outcomes obtained are low.

\section{CONCLUSION}

Based on the findings of this study, it can be concluded that the learning outcomes of mathematics taught by the learning model of concept attainment are higher than the direct learning model. There is an influence of the interaction between the learning model and SDL on the learning outcomes of mathematics. Mathematics learning outcomes for students who have high SDL and are taught with a learning model of concept attainment is higher than the direct learning model, and students who have low 
SDL are taught with a learning model of concept attainment lower than the direct learning model.

The next researcher is expected to be able to apply the concept achievement learning model to improve mathematics learning outcomes by increasing the research sample at the secondary school level.

\section{RECOMMENDATIONS}

Based on the findings of this study, it is recommended as follows: (1) learning model of concept attainment must be applied in mathematics learning to instill mathematical concepts in improving student mathematics learning outcomes, (2) in mathematics learning need to pay attention to the characteristics of students especially SDL in applying learning models, and (3) students who have high SDL should be taught with the SDL learning model, while students who have low SDL are taught with a direct learning model.

\section{REFERENCES}

Abed, A. Z., Sameer, S. A., Kasim, M. A., \& Othman, A. T. (2019). Predicting effect implementing the jigsaw strategy on the academic achievement of students in mathematics classes. International Electronic Journal of Mathematics Education, 15(1), em0558.

Adeniji, S. M., Ameen, S. K., Dambatta, B. U., \& Orilonise, R. (2018). Effect of mastery learning approach on senior school students' academic performance and retention in circle geometry. International Journal of Instruction, 11(4), 951-962.

Agrawal, J., \& Morin, L. L. (2016). Evidence-based practices: Applications of concrete representational abstract framework across math concepts for students with mathematics disabilities. Learning Disabilities Research \& Practice, 31(1), 34-44.

Akgunduz, D., \& Akinoglu, O. (2016). The effect of blended learning and social mediasupported learning on the students' attitude and self-directed learning skills in science education. Turkish Online Journal of Educational Technology-TOJET, 15(2), 106-115.

Alotaibi, K. N. (2016). The learning environment as a mediating variable between selfdirected learning readiness and academic performance of a sample of Saudi nursing and medical emergency students. Nurse Education Today, 36, 249-254.

Andrew, D. P., \& Pedersen, P. M. (2018). Research methods and design in sport management. Human Kinetics.

Angraini, L. M., Kusumah, Y. S., \& Dahlan, J. A. (2018, May). The enhancement of mathematical analogical reasoning ability of university students through concept attainment model. In Journal of Physics: Conference Series (Vol. 1013, No. 1, p. 012111). IOP Publishing. 
Bagheri, M., Ali, W. Z. W., Abdullah, M. C. B., \& Daud, S. M. (2013). Effects of project-based learning strategy on self-directed learning skills of educational technology students. Contemporary educational technology, 4(1), 15-29.

Baroody, A. J., \& Dowker, A. (Eds.). (2013). The development of arithmetic concepts and skills: Constructive adaptive expertise. Routledge.

Borich, G. D. (2017). Effective teaching methods: Research-based practice. Boston: Pearson.

Brockett, R. G., \& Hiemstra, R. (2018). Self-direction in adult learning: Perspectives on theory, research and practice. Routledge.

BSNP. (2006). Permendiknas No. 22 Tahun 2006 tentang Standar Isi untuk Satuan Pendidikan Dasar dan Menengah. Jakarta: Depdiknas.

Burden, P. R., \& Byrd, D. M. (2016). Methods for effective teaching: Meeting the needs of all students. Allyn \& Bacon.

Capar, G., \& Tarim, K. (2015). Efficacy of the cooperative learning method on mathematics achievement and attitude: A meta-analysis research. Educational Sciences: Theory and Practice, 15(2), 553-559.

Chase, C. C., \& Klahr, D. (2017). Invention versus direct instruction: For some content, it'sa tie. Journal of Science Education and Technology, 26(6), 582-596.

Croasmun, J. T., \& Ostrom, L. (2011). Using likert-type scales in the social sciences. Journal of Adult Education, 40(1), 19-22.

Din, N., Haron, S., \& Rashid, R. M. (2016). Can self-directed learning environment improve quality of life? Procedia-Social and Behavioral Sciences, 222, 219-227.

Eggen, P. D., \& Kauchak, D. P. (2012). Strategies and models for teachers: Teaching content and thinking skills. Boston, MA: Pearson/Allyn and Bacon.

Estes, T. H., \& Mintz, S. L., (2016). Instruction: A models approach. Pearson.

Gatti, L., Ulrich, M., \& Seele, P. (2019). Education for sustainable development through business simulation games: An exploratory study of sustainability gamification and its effects on students' learning outcomes. Journal of Cleaner Production, 207, 667-678.

Herlo, D. (2017). Self-directed learning on teacher training studies programs. Educația Plus, 18(2), 7-17.

Huang, C. S., Su, A. Y., Yang, S. J., \& Liou, H. H. (2017). A collaborative digital pen learning approach to improving students' learning achievement and motivation in mathematics courses. Computers \& Education, 107, 31-44.

Joyce, B., Weil, M., \& Calhoun, E. (2015). Models of teaching. Allyn and Bacon.

Judd, C. M., McClelland, G. H., \& Ryan, C. S. (2017). Data analysis: a model comparison approach to regression, ANOVA, and beyond. Routledge. 
Kaplan, R. M., \& Saccuzzo, D. P. (2017). Psychological testing: Principles, applications, and issues. Nelson Education.

Khiat, H. (2017). Academic performance and the practice of self-directed learning: The adult student perspective. Journal of further and Higher Education, 41(1), 44-59.

Kilbane, C. R., \& Milman, N. B. (2014). Teaching models: Designing instruction for 21 st century learners. Pearson Higher Ed.

Kim, H. S. (2002). We talk, therefore we think? A cultural analysis of the effect of talking on thinking. Journal of Personality and Social Psychology, 83(4), 828.

Kholodnaya, M. A. (2016). Development-focused educational texts as a basis for learners' intellectual development in studying mathematics (DET technology). Psychology in Russia, 9(3), 24.

La Trobe, H. L., \& Acott, T. G. (2000). A modified NEP/DSP environmental attitudes scale. The Journal of Environmental Education, 32(1), 12-20.

León, J., Núñez, J. L., \& Liew, J. (2015). Self-determination and STEM education: Effects of autonomy, motivation, and self-regulated learning on high school math achievement. Learning and Individual Differences, 43, 156-163.

Maonde, F., Nurmuiza, I., \& Sani, A. (2016). The effect of motivation on mathematics achievement through combination of cooperative learning model. International Journal of Contemporary Applied Sciences, 3(6), 78-97.

Maonde, F., Bey, A., Salam, M., Suhar, L., Anggo, M., \& Tiya, K. (2015). The discrepancy of students' mathematic achievement through cooperative learning model, and the ability in mastering languages and science. International Journal of Education and Research, 3(1), 141-158.

Markant, D. B., Settles, B., \& Gureckis, T. M. (2016). Self-directed learning favors local, rather than global, uncertainty. Cognitive science, 40(1), 100-120.

Maxwell, S. E., Delaney, H. D., \& Kelley K. (2018). Designing experiments and analyzing data: A model comparison perspective, $3^{\text {th }}$ ed. Routledge.

Minarni, A., Napitupulu, E., \& Husein, R. (2016). Mathematical understanding and representation ability of public junior high school in north Sumatra. Journal on Mathematics Education, 7(1), 43-56.

Mondal, B. C. (2013). Teaching science through information processing model. Journal of education and practice, $4(9)$.

Moore, K. D. (2015). Effective instructional strategies: From theory to practice. Sage Publications.

Moyer-Packenham, P. S., \& Westenskow, A. (2013). Effects of virtual manipulatives on student achievement and mathematics learning. International Journal of Virtual and Personal Learning Environments, 4(3), 35-50. 
Mulbar, U., Rahman, A., \& Ahmar, A. (2017). Analysis of the ability in mathematical problem-solving based on SOLO taxonomy and cognitive style. World Transactions on Engineering and Technology Education, 15(1).

Mullis, I. V., \& Martin, M. O. (2017). TIMSS 2019 assessment frameworks. Amsterdam: International Association for the Evaluation of Educational Achievement. Herengracht.

Nasri, N. M., \& Mansor, A. N. (2016). Teacher educators' perspectives on the sociocultural dimensions of self-directed learning. Education, 7, 2755-2773.

Nasution, Y. S., \& Surya, E. (2017). Application of TPS type cooperative learning in improving student's mathematics learning outcomes. International Journal of Sciences Basic and Applied Research (IJSBAR), 34(1), 116-125.

Ningsih, Y. L., \& Paradesa, R. (2018). Improving students' understanding of mathematical concept using maple. In Journal of Physics: Conference Series (Vol. 948, No. 1, p. 012034). IOP Publishing.

Nystrand, M., Wu, L. L., Gamoran, A., Zeiser, S., \& Long, D. A. (2003). Questions in time: Investigating the structure and dynamics of unfolding classroom discourse. Discourse processes, 35(2), 135-198.

Park, D., Gunderson, E. A., Tsukayama, E., Levine, S. C., \& Beilock, S. L. (2016). Young children's motivational frameworks and math achievement: Relation to teacherreported instructional practices, but not teacher theory of intelligence. Journal of Educational Psychology, 108(3), 300.

Paulhus, D. L., Duncan, J. H., \& Yik, M. S. (2002). Patterns of shyness in East-Asian and European-heritage students. Journal of Research in Personality, 36(5), 442-462.

Rahman, A., Ahmar, A., \& Rusli, R. (2016). The influence of cooperative learning models on learning outcomes based on students' learning styles. World Transactions on Engineering and Technology Education, 14(3).

Rahman, A., \& Ahmar, A. (2017). Relationship between learning styles and learning achievement in mathematics based on genders. World Transactions on Engineering and Technology Education, 15(1).

Rana, S., Ardichvili, A., \& Polesello, D. (2016). Promoting self-directed learning in a learning organization: tools and practices. European Journal of Training and Development, 40(7), 470-489.

Rashid, T., \& Asghar, H. M. (2016). Technology use, self-directed learning, student engagement and academic performance: Examining the interrelations. Computers in Human Behavior, 63, 604-612.

Razak, F. (2016). The effect of cooperative learning on mathematics learning outcomes viewed from students' learning motivation. JRAMathEdu (Journal of Research and Advances in Mathematics Education), 1(1), 49-55. 
Rensaa, R. J. (2014). The impact of lecture notes on an engineering student's understanding of mathematical concepts. The Journal of Mathematical Behavior, 34, 33-57.

Richland, L. E., Begolli, K. N., Simms, N., Frausel, R. R., \& Lyons, E. A. (2017). Supporting mathematical discussions: The roles of comparison and cognitive load. Educational Psychology Review, 29(1), 41-53.

Salam, M., Ibrahim, N., \& Sukardjo, M. (2019, April). The effect of learning model and spatial intelligence on learning outcome. In 1st International Conference on Advanced Multidisciplinary Research (ICAMR 2018). Atlantis Press.

Salam, M., Ibrahim, N., \& Sukardjo, M. (2019). Effects of instructional models and spatial intelligence on the mathematics learning outcomes after controlling for students' initial competency. International Journal of Instruction, 12(3), 699-716.

Sawatsky, A. P., Ratelle, J. T., Bonnes, S. L., Egginton, J. S., \& Beckman, T. J. (2017). A model of self-directed learning in internal medicine residency: a qualitative study using grounded theory. BMC medical education, 17(1), 31.

Seel, N. M. (2012). Encyclopedia of the sciences of learning. Springer.

Sharma, A., \& Pachauri, D. (2016). Comparison of advance organizer and concept attainment model for teaching concepts of science to standard IX. International Journal of Educational Research and Technology, 7(1).

Silén, C., \& Uhlin, L. (2008). Self-directed learning-a learning issue for students and faculty! Teaching in Higher Education, 13(4), 461-475.

Suarsana, I., Lestari, I. A. P. D., \& Mertasari, N. M. S. (2019). The effect of online problem posing on students' problem-solving ability in mathematics. International Journal of Instruction, 12(1), 809-820.

Sumarni, S., Darhim, D., Fatimah, S., Priatna, N., Anjelita, A., \& Taufik, A. (2018). The students' mathematical concept understanding ability through cooperative learning type jigsaw assisted visual media. In Journal of Physics: Conference Series (Vol. 1132, No. 1, p. 012051). IOP Publishing.

Tabach, M., \& Nachlieli, T. (2016). Communicational perspectives on learning and teaching mathematics: prologue. Educational Studies in Mathematics, 91(3), 299-306.

Takaendengan, B. R., \& Santosa, R. H. (2018, September). Using Moodle to improve self-directed learning of mathematics in vocational school. In Journal of Physics: Conference Series (Vol. 1097, No. 1, p. 012121). IOP Publishing.

Tan, L., \& Koh, J. (2014). Self-directed learning: Learning in the 21st century education.

Tan, S. C., Divaharan, S., Tan, L., \& Cheah, H. M. (2011). Self-directed learning with ICT: Theory, practice and assessment. Ministry of Education, Singapore. 
Wang, Z., Lukowski, S. L., Hart, S. A., Lyons, I. M., Thompson, L. A., Kovas, Y., \& Petrill, S. A. (2015). Is math anxiety always bad for math learning? The role of math motivation. Psychological science, 26(12), 1863-1876.

Weintrop, D., Beheshti, E., Horn, M., Orton, K., Jona, K., Trouille, L., \& Wilensky, U. (2016). Defining computational thinking for mathematics and science classrooms. Journal of Science Education and Technology, 25(1), 127-147.

Zhang, X., Räsänen, P., Koponen, T., Aunola, K., Lerkkanen, M. K., \& Nurmi, J. E. (2018). Early cognitive precursors of children's mathematics learning disability and persistent low achievement: A 5-year longitudinal study. Child development. 